\title{
Managing medicines in alcohol-associated liver disease: a practical review
}

\section{Amy L Johnson (i) \\ Hepatology research \\ fellow $w^{12}$ \\ Kelly L Hayward (D) Clinical research fellow', Liver disease pharmacist ${ }^{2}$ \\ ${ }^{1}$ Centre for Liver Disease Research, Faculty of Medicine, Translational Research Institute, The University of Queensland, Brisbane \\ ${ }^{2}$ Department of Gastroenterology and Hepatology, Princess Alexandra Hospital, Brisbane}

\section{Keywords}

alcoholic hepatitis, alcoholic cirrhosis, drug therapy management, malnourishment

Aust Prescr 2021;44:96-106 https://doi.org/10.18773/ austprescr.2021.015

\section{SUMMARY}

People with alcohol-associated liver disease often take medicines to manage complications of liver disease and comorbidities. However, patients may be at increased risk of drug-related harm.

Assessing the severity of liver disease is fundamental to management, as disease staging (steatosis, early fibrosis, cirrhosis) affects medication safety and guides treatment.

While clinically significant pharmacokinetic and pharmacodynamic changes predominantly occur in cirrhosis, people with early alcohol-associated liver disease may still experience adverse events with potentially inappropriate medicines such as proton pump inhibitors, opioids and benzodiazepines.

Regular medication review is essential to ensure ongoing appropriateness and safety.

Alcoholic hepatitis and cirrhosis require specialist gastroenterology or hepatology management. However, general practitioners will remain the cornerstone of day-to-day medication management.

\section{Introduction}

Alcohol-associated liver disease is one of the major causes of chronic liver disease in Australia. National guidelines recommend healthy adults consume no more than 10 standard drinks per week and a maximum of four standard drinks on any one day. However, the Australian Bureau of Statistics 2017-18 National Health Survey found that $16.1 \%$ of adults drank an average of at least two standard drinks per day, and $42.1 \%$ consumed more than four standard drinks on one occasion in the past year. ${ }^{2}$

Alcohol use disorder is a severe chronic drinking problem that is characterised by impaired ability to stop or control alcohol use despite adverse social, occupational or health consequences. ${ }^{3}$ The risk of developing alcohol-associated liver disease increases with the amount of alcohol consumed. ${ }^{4}$ Between 10 and $35 \%$ of excessive drinkers will develop advanced disease. ${ }^{4}$ People with alcohol-associated liver disease are also at greater risk of cirrhosis-related complications ('decompensation') and liver-related death compared to other chronic liver diseases. ${ }^{5}$ It is important to note that there are no safe limits of alcohol use in patients with alcohol-associated liver disease.

Optimising medicines to manage complications of liver disease and comorbidities can be difficult due to:

- heterogeneity in patient behaviour (variable medication adherence, compliance with monitoring tests and scans, engagement with health services)

- limited pharmacotherapy options to manage alcohol use disorder and treat certain complications of advanced disease
- changes to pharmacokinetic and pharmacodynamic characteristics (due to liver disease and malnourishment)

- the potential for interactions with alcohol itself. Primary care clinicians are ideally placed to improve medication safety by reviewing and monitoring a patient's medicines and reducing use of potentially inappropriate medicines.

\section{Diagnosis and staging of alcohol- associated liver disease}

The role of medicines in alcohol-associated liver disease and the goals of treatment evolve with progression of disease. Optimisation of medicine use and minimisation of medicine-related harm therefore relies on appropriate staging.

The pathogenesis of alcohol-associated liver disease is complex. The disease spectrum ranges from simple hepatic steatosis to more advanced forms, including alcoholic hepatitis, alcoholic cirrhosis, and acute-on-chronic liver failure (see Fig.). ${ }^{6}$ Investigations to assist with staging include medical imaging (ultrasound, magnetic resonance imaging, computed tomography), transient elastography (FibroScan), and tests such as Fibrosis-4, aspartate aminotransferase:alanine aminotransferase ratio, and aspartate aminotransferase platelet ratio index. ${ }^{7,8}$

Unlike renal disease, in which there are relatively reliable measures of glomerular filtration, there is no simple measure of hepatic function to guide drug dosing in liver disease. However, patterns and markers 


\section{Fig. Progression of alcohol-associated liver disease}

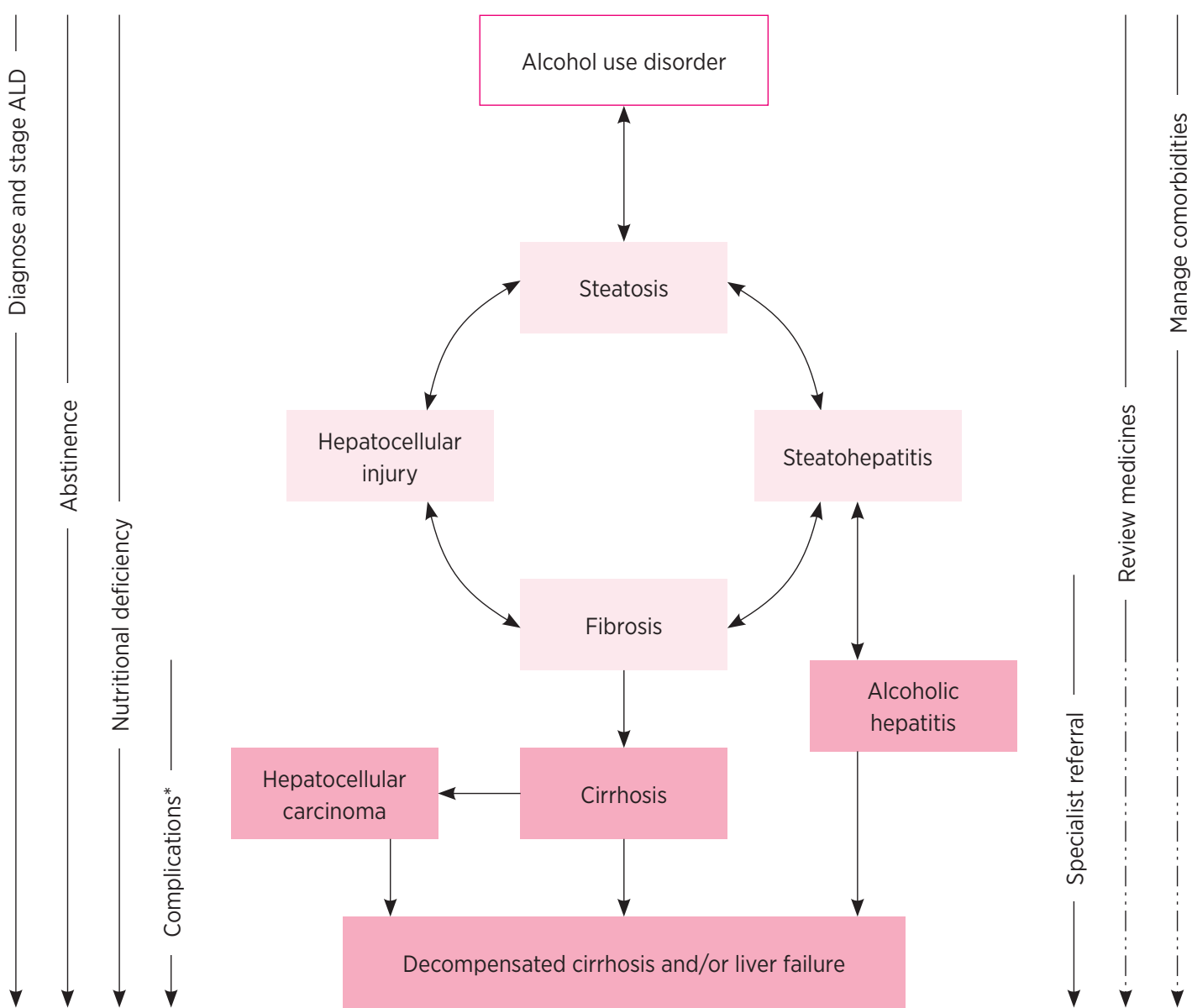

Key:

Patient management goal

-...-... Dose adjustment may be required

* Complications of cirrhosis and portal hypertension, including ascites, spontaneous bacterial peritonitis, hepatic encephalopathy and variceal bleeding

Risk factors for progressive liver injury include pattern of alcohol consumption (daily drinking, drinking while fasting, binge drinking), comorbid conditions (chronic viral hepatitis, haemochromatosis, non-alcoholic fatty liver disease), smoking cigarettes, female gender, increased body mass index, and genetic factors.

ALD alcohol-associated liver disease

in common blood tests can suggest acute hepatic inflammation or impaired synthetic function and may assist decision making regarding the safety of medicines (Table 1). ${ }^{9-17}$

\section{Medicines in active drinkers}

Interactions between alcohol and medicines can occur in active drinkers. For example, drugs that accelerate gastric emptying (e.g. metoclopramide, domperidone, erythromycin) and those that inhibit alcohol dehydrogenase activity (e.g. aspirin, ranitidine) may result in higher blood alcohol concentrations. ${ }^{18}$ This can subsequently increase the risk of pharmacodynamic interactions with sedatives, anticholinergics and antidepressants, and cause symptoms such as increased drowsiness, sedation and decreased motor skills.

Pharmacokinetic interactions with aldehyde dehydrogenase (e.g. disulfiram, metronidazole) can lead to rapid accumulation of ethanol's bioactive metabolite acetaldehyde and significant adverse effects. ${ }^{18,19}$ Upregulation of cytochrome P450 2E1 in chronic alcohol use can also affect the metabolism of other drugs (e.g. paracetamol, phenobarbital).18,20 These interactions depend on genetic variability and the presence or absence of alcohol as a competitive substrate. 
Table 1 Abnormal blood tests and medication considerations in people with alcohol-associated liver disease ${ }^{9-17}$

\begin{tabular}{|c|c|c|}
\hline Parameter & Test result & Comment \\
\hline \multirow{6}{*}{$\begin{array}{l}\text { Aspartate } \\
\text { aminotransferase } \\
\text { (AST)* }\end{array}$} & Usually $<8$ times upper limit of normal. ${ }^{\dagger}$ & \multirow{17}{*}{$\begin{array}{l}\text { Review drugs that may contribute to } \\
\text { liver function test derangement and } \\
\text { hyperbilirubinaemia: } \\
\text { - antibiotics } \\
\text { - antiepileptics } \\
\text { - herbal and dietary supplements } \\
\text { - paracetamol } \\
\text { - statins. } \\
\text { These tests do not reflect hepatic capacity to } \\
\text { metabolise or clear medications, except where } \\
\text { acute liver failure or cirrhosis is suspected. }\end{array}$} \\
\hline & AST is often higher than ALT with a ratio >1:1. & \\
\hline & Typically between $50-400 \mathrm{IU} / \mathrm{mL}$ in alcoholic & \\
\hline & hepatitis with AST often higher than ALT & \\
\hline & $($ ratio $>2: 1)$ & \\
\hline & May be 'normal' in cirrhosis. & \\
\hline \multirow{4}{*}{$\begin{array}{l}\text { Alanine } \\
\text { aminotransferase } \\
(\mathrm{ALT})^{*}\end{array}$} & \multirow{4}{*}{$\begin{array}{l}\text { Usually }<5 \text { times upper limit of normal. }{ }^{\dagger} \\
\text { Elevated in alcoholic hepatitis but usually } \\
<400 \mathrm{IU} / \mathrm{mL} \text { with ALT often lower than AST } \\
\text { as above. } \\
\text { Mav be 'normal' in cirrhosis. }\end{array}$} & \\
\hline & & \\
\hline & & \\
\hline & & \\
\hline $\begin{array}{l}\text { Alkaline } \\
\text { phosphatase }\end{array}$ & Usually <2-3 times upper limit of normal. & \\
\hline \multirow[t]{3}{*}{$\begin{array}{l}\text { Gamma-glutamyl } \\
\text { transferase }\end{array}$} & $\begin{array}{l}\text { Often elevated in heavy drinkers, but non- } \\
\text { specific. Other causes of elevation include: }\end{array}$ & \\
\hline & - biliary obstruction/disease & \\
\hline & - medications (e.g. phenytoin, barbiturates). & \\
\hline \multirow[t]{3}{*}{ Bilirubin } & $\begin{array}{l}\text { Often elevated ( }>50 \text { micromol/L) in alcoholic } \\
\text { hepatitis and cirrhosis due to impaired liver } \\
\text { synthetic function. }\end{array}$ & \\
\hline & $\begin{array}{l}\text { Higher bilirubin concentrations indicate more } \\
\text { severe alcoholic hepatitis and onset of jaundice } \\
\text { usually occurs within the preceding } 8 \text { weeks. }\end{array}$ & \\
\hline & $\begin{array}{l}\text { Elevation can signify decompensation } \\
\text { in cirrhosis. }\end{array}$ & \\
\hline \multirow[t]{2}{*}{ Haemoglobin } & \multirow{2}{*}{$\begin{array}{l}\text { May be low in all stages of alcohol-associated } \\
\text { liver disease due to multiple factors. }\end{array}$} & Check iron studies and replace if deficient. \\
\hline & & $\begin{array}{l}\text { Anticoagulant and antiplatelet therapies } \\
\text { for comorbidities should be continued (if } \\
\text { indicated) unless bleeding is suspected. }\end{array}$ \\
\hline \multirow[t]{3}{*}{$\begin{array}{l}\text { Lymphocytes and } \\
\text { neutrophils }\end{array}$} & $\begin{array}{l}\text { May be reduced in portal hypertension and } \\
\text { cirrhosis due to hypersplenism. }\end{array}$ & $\begin{array}{l}\text { Use drugs that can impair immunity with } \\
\text { caution and monitor regularly: }\end{array}$ \\
\hline & \multirow{2}{*}{$\begin{array}{l}\text { White cell count is elevated in alcoholic hepatitis, } \\
\text { but usually }<20 \times 10^{9} / \mathrm{L} \text { (largely neutrophils). }\end{array}$} & - corticosteroids \\
\hline & & - azathioprine. \\
\hline \multirow[t]{3}{*}{$\begin{array}{l}\text { International } \\
\text { normalised ratio/ } \\
\text { prothrombin time }\end{array}$} & \multirow[t]{3}{*}{$\begin{array}{l}\text { Often elevated in alcoholic hepatitis } \\
\text { and cirrhosis due to impaired synthetic } \\
\text { function and reduced hepatic production of } \\
\text { coagulation factors. }\end{array}$} & $\begin{array}{l}\text { INR is a good measure of liver } \\
\text { synthetic function but not bleeding } \\
\text { risk. Decompensated cirrhosis is a } \\
\text { prothrombotic state. }\end{array}$ \\
\hline & & $\begin{array}{l}\text { Monitoring parameters for anticoagulant } \\
\text { therapies (warfarin, heparin, low-molecular- } \\
\text { weight heparin) may be less reliable. }\end{array}$ \\
\hline & & $\begin{array}{l}\text { Vitamin } \mathrm{K} \text { supplementation is only helpful } \\
\text { in deficiency. }\end{array}$ \\
\hline \multirow[t]{4}{*}{ Albumin } & \multirow{4}{*}{$\begin{array}{l}\text { May be reduced in alcoholic hepatitis and } \\
\text { cirrhosis due to impaired synthetic function } \\
\text { and reduced hepatic production of proteins. }\end{array}$} & $\begin{array}{l}\text { Distribution of highly protein-bound drugs } \\
\text { may be altered: }\end{array}$ \\
\hline & & - valproate, phenytoin \\
\hline & & - warfarin \\
\hline & & - diazepam. \\
\hline
\end{tabular}


Table 1 Abnormal blood tests and medication considerations in people with alcohol-associated liver disease ${ }^{9-17}$ (continued)

\begin{tabular}{|c|c|c|}
\hline Parameter & Test result & Comment \\
\hline Platelets & $\begin{array}{l}\text { Often low in cirrhosis due to bone marrow } \\
\text { suppression and splenic sequestration } \\
\text { associated with portal hypertension. }\end{array}$ & $\begin{array}{l}\text { Prophylactic use of heparin and low- } \\
\text { molecular-weight heparin is usually avoided, } \\
\text { particularly when platelet count }<50 \times 10^{9} / \mathrm{L} \text {. } \\
\text { Use of aspirin in coronary artery disease } \\
\text { appears safe. }\end{array}$ \\
\hline Sodium & $\begin{array}{l}\text { May be low in alcoholic hepatitis and cirrhosis } \\
\text { due to altered renal haemodynamics, renin- } \\
\text { angiotensin-aldosterone system dysregulation } \\
\text { and fluid accumulation. }\end{array}$ & $\begin{array}{l}\text { Avoid or carefully monitor drugs that may } \\
\text { worsen hyponatraemia or renal function: } \\
\text { - ACE inhibitors, sartans } \\
\text { - diuretics. }\end{array}$ \\
\hline \multirow[t]{3}{*}{ Creatinine } & $\begin{array}{l}\text { May be elevated in decompensation, } \\
\text { hepatorenal syndrome and severe } \\
\text { alcoholic hepatitis. }\end{array}$ & $\begin{array}{l}\text { Have a low index of suspicion for acute renal } \\
\text { impairment in people with cirrhosis due to low } \\
\text { baseline creatinine. }\end{array}$ \\
\hline & $\begin{array}{l}\text { Baseline creatinine may be low in cirrhosis due } \\
\text { to low muscle mass. }\end{array}$ & $\begin{array}{l}\text { Use medicines that may affect renal function } \\
\text { with caution and monitor required therapies } \\
\text { regularly (e.g. diuretics). }\end{array}$ \\
\hline & & $\begin{array}{l}\text { Nephrotoxic drugs are often withheld in } \\
\text { severe alcoholic hepatitis to prevent or } \\
\text { manage acute kidney injury and hepatorenal } \\
\text { syndrome, which negatively impact survival. }\end{array}$ \\
\hline
\end{tabular}

* Transaminases $>400 \mathrm{IU} / \mathrm{mL}$ should raise suspicion of other causes of acute liver injury.

+ Degree of elevation does not correlate with alcohol-associated liver disease severity.

$\ddagger$ Clinical history usually includes heavy alcohol use (>40 g/day in women, $>60 \mathrm{~g} /$ day in men) for at least 6 months with fewer than 60 days of abstinence before onset of jaundice.

Despite the potential for increased bioactivation to its toxic metabolite, paracetamol is generally considered safe for most people with alcohol-associated liver disease and is preferred over non-steroidal antiinflammatory drugs in advanced disease. ${ }^{21}$ Dose reduction to a maximum $2-3 \mathrm{~g}$ of paracetamol daily is recommended for malnourished patients and those with cirrhosis. ${ }^{20,21}$

\section{Abstinence and withdrawal}

Intervention to support abstinence is essential, as cessation of drinking reduces the risk of liver disease progression, and cirrhosis-related complications, and it improves clinical outcomes at all stages. ${ }^{6,22,23}$ In addition to psychosocial treatments, pharmacotherapy may be prescribed to support abstinence. ${ }^{24}$ Therapies available on the Pharmaceutical Benefits Scheme in Australia include naltrexone and acamprosate. Disulfiram is also used but is only available on private prescription (Table 2). 9,16,19,24-31 These medicines have modest efficacy and most have limited or no published safety data in people with cirrhosis and should only be considered under specialist guidance. ${ }^{6}$ Other medicines including gabapentin, baclofen and topiramate may be prescribed off label by specialists to assist relapse prevention, but evidence for their effectiveness is limited.6,24

\section{Benzodiazepines}

In heavy drinkers who suddenly discontinue or decrease alcohol consumption, benzodiazepines may be used short term with other supportive measures to manage withdrawal symptoms. ${ }^{28}$ The Clinical Institute Withdrawal Assessment for Alcohol Revised (CIWA-Ar) Score ${ }^{32}$ can assist the evaluation of alcohol withdrawal syndrome severity and benzodiazepine requirements. Patients with moderate or severe alcohol withdrawal syndrome are usually managed in hospital, but small doses of benzodiazepine may be continued for a short duration on discharge. Diazepam is usually preferred because of its long halflife, although oxazepam may be safer in cirrhosis. ${ }^{28}$

Outside the setting of alcohol withdrawal, benzodiazepines are potentially inappropriate. They should be prescribed with extreme caution (especially in cirrhosis) as the risk of adverse effects may outweigh the benefits. The decision to prescribe benzodiazepines in alcohol-associated liver disease should be made on a case-by-case basis as patients may be at increased risk of harm due to pharmacodynamic interactions. Benzodiazepines have also been associated with an increased risk of first-time hepatic encephalopathy in cirrhosis when taken for 3-10 days. ${ }^{29}$ 


\section{Table 2 Commonly used medicines in different stages of alcohol-associated liver disease 9,16,19,24-31 $^{2}$}

\begin{tabular}{|c|c|c|c|}
\hline Drugs & $\begin{array}{l}\text { Indication and mechanism of } \\
\text { action }\end{array}$ & $\begin{array}{l}\text { Precautions and } \\
\text { contraindications }\end{array}$ & Comments \\
\hline
\end{tabular}

\section{Alcohol abstinence}

$\begin{array}{lll}\text { Acamprosate } & \begin{array}{l}\text { Reduces symptoms of alcohol } \\ \text { withdrawal (e.g. anxiety, irritability, }\end{array} & \begin{array}{l}\text { Contraindicated: Child-Pugh C } \\ \text { cirrhosis, renal impairment (serum }\end{array} \\ \begin{array}{l}\text { insomnia, cravings, neuronal } \\ \text { hyperexcitability). }\end{array} & \begin{array}{l}\text { creatinine }>120 \mathrm{micromol} / \mathrm{L} \text { or } \\ \text { creatinine clearance } \leq 30 \mathrm{~mL} / \mathrm{min} \text { ). } \\ \text { Modulates the glutamatergic }\end{array} & \begin{array}{l}\text { Caution: acute alcohol withdrawal, } \\ \text { receptor system. }\end{array} \\ \end{array}$

Naltrexone

Attenuates cravings and reduces pleasurable effects following alcohol consumption.

Reversible inhibition of opioid receptors.

Disulfiram

Interference with alcohol metabolism.

Irreversible inhibition of aldehyde dehydrogenase results in raised blood acetaldehyde concentrations and unpleasant effects if alcohol is consumed.

\section{Contraindicated: opioid} dependence, severe hepatic impairment, acute hepatitis.

Caution: renal impairment, liver enzymes $>3$ times upper limit of normal.

Contraindicated: current alcohol intoxication, ischaemic heart disease, severe myocardial disease, severe renal impairment, severe hepatic impairment, acute psychosis, cirrhosis.

Caution: cardiovascular disease, diabetes, hypothyroidism, epilepsy, chronic kidney disease, hepatic impairment.
Not hepatically metabolised but requires dose adjustment in renal impairment.

Alcohol-induced psychomotor impairment will still occur if alcohol is consumed.

Commence after the acute phase of alcohol withdrawal has passed (i.e. 1 week after the last drink).

Risk of hepatotoxicity in hepatic and renal impairment.

Alcohol-induced psychomotor impairment will still occur if alcohol is consumed.

Use non-opioid analgesics (e.g. paracetamol) if pain relief is required.

Not recommended in moderate-severe liver disease due to lack of safety data.

Extensive patient and carer education required before starting disulfiram.

Adverse effects of a disulfiram-alcohol reaction can be severe, including respiratory depression, seizures, arrhythmia, myocardial infarction and worsening of acute congestive heart failure in patents with pre-existing cardiac conditions. Numerous potential drug-drug interactions.

\section{Alcohol withdrawal syndrome}

Benzodiazepines:

- diazepam, oxazepam
Reduce acute alcohol withdrawal symptoms and seizure risk.

Modulate neuronal hyperexcitability by stimulating gammaaminobutyric acid (GABA) receptors.
Caution: may precipitate hepatic encephalopathy in patients with cirrhosis or acute liver failure.
Short-acting benzodiazepines with uncomplicated hepatic metabolism (e.g. oxazepam) are preferred in people with cirrhosis and the elderly.

\section{Alcoholic hepatitis}

Corticosteroids:

Modulate inflammatory response.

- prednisolone
May improve short-term survival in severe alcoholic hepatitis.
Contraindicated: untreated infection, gastrointestinal bleeding, renal failure, acute psychosis, pancreatitis (uncontrolled hyperglycaemia).

Caution: diabetes, peptic ulcer disease.

\section{Nutritional deficiency}

Thiamine $\left(B_{1}\right)$

Other B vitamins:

- pyridoxine $\left(\mathrm{B}_{6}\right)$ folic acid $\left(B_{9}\right)$, cyanocobalamin $\left(B_{12}\right)$
Chronic thiamine deficiency can lead to nutritional encephalopathy (Wernicke-Korsakoff's syndrome).

\section{Prevent complications of deficiency} including cognitive dysfunction, peripheral neuropathy, and anaemia.

Vitamin B deficiencies are common in alcohol-associated liver disease.

Thiamine doses contained in over-the-counter oral supplements may be insufficient.

Caution: folic acid supplementation should be avoided in megaloblastic anaemia until $B_{12}$ deficiency is corrected.
Started in hospital with other supportive care.

Short-term use only (up to 4 weeks with optional 3-week taper thereafter).

\section{evidence is lacking for long-term use.}

Specific deficiencies should be corrected, but 
Table 2 Commonly used medicines in different stages of alcohol-associated liver disease ${ }^{9,16,19,24-31}$ (continued)

\begin{tabular}{lll} 
Drugs & $\begin{array}{l}\text { Indication and mechanism of } \\
\text { action }\end{array}$ & $\begin{array}{l}\text { Precautions and } \\
\text { contraindications }\end{array}$ \\
\hline
\end{tabular}

\section{Nutritional deficiency (continued)}

\begin{tabular}{|c|c|c|c|}
\hline Vitamin D & $\begin{array}{l}\text { Regulates absorption of essential } \\
\text { minerals including calcium, } \\
\text { magnesium and phosphate. } \\
\text { Vitamin D deficiency is common in } \\
\text { patients with cirrhosis. }\end{array}$ & $\begin{array}{l}\text { Caution: severe renal impairment, } \\
\text { hypercalcaemia. }\end{array}$ & $\begin{array}{l}\text { Evidence for vitamin D supplementation in } \\
\text { chronic liver disease is inconclusive. } \\
\text { Supplement if deficient or in the presence of } \\
\text { other indications (e.g. bone disease). }\end{array}$ \\
\hline Zinc & $\begin{array}{l}\text { Prevents complications of } \\
\text { deficiency including cognitive } \\
\text { dysfunction, hypogonadism, altered } \\
\text { immune function and impaired } \\
\text { wound healing. } \\
\text { Improves gut-mucosal barrier } \\
\text { integrity. } \\
\text { Zinc deficiency is common } \\
\text { and worsens with disease } \\
\text { progression. }\end{array}$ & Caution: severe renal impairment. & $\begin{array}{l}\text { Evidence supports zinc supplementation to } \\
\text { correct deficiency in alcohol-associated liver } \\
\text { disease, especially in people with cirrhosis and } \\
\text { alcoholic hepatitis. }\end{array}$ \\
\hline
\end{tabular}

\section{Complications of advanced liver disease (managed by a specialist)}

Non-selective beta blockers:

- propranolol, carvedilol
Prevent bleeding from gastrooesophageal varices.

Induce splanchnic vasoconstriction, thereby decreasing portal blood flow and reducing portal hypertension.
Caution: bradycardia

(45-50 beats/min), severe hypotension, peripheral arterial disease, diabetes, poorly controlled asthma, severe hepatic impairment (carvedilol).
Diuretics:

- spironolactone, furosemide (frusemide)
Treat fluid overload (e.g. ascites, hepatic hydrothorax).

Promote excretion of sodium and water.
Contraindicated: renal failure, severe sodium and fluid depletion.

Caution: renal impairment (creatinine clearance $<30 \mathrm{~mL} / \mathrm{min}$ ), electrolyte derangement.

Usually started at a low dose (propranolol and carvedilol are hepatically metabolised) and titrated to achieve a resting heart rate of $55-60$ beats/min while maintaining systolic blood pressure $\geq 90 \mathrm{mmHg}$.

Selective beta blockers (metoprolol, bisoprolol) are not effective.

Carvedilol is not PBS-listed for this indication.

No significant pharmacokinetic changes in liver impairment, but patients may be at increased risk of harmful pharmacodynamic interactions.

Regular monitoring of fluid status, renal function and electrolytes is required.

Patients are usually on a salt-restricted diet.

Usually started by a specialist following an episode of spontaneous bacterial peritonitis in patients with persistent ascites.

Proton pump inhibitors can increase the risk of spontaneous bacterial peritonitis.

In patients with genuine intolerance to lactulose, macrogol-containing laxatives can be used.

Usually titrated to achieve 2-3 loose bowel motions each day. thereby reducing production and absorption of ammonia.

Prevent recurrent hepatic encephalopathy.

Modify gut flora and reduce production of ammonia.
Contraindicated: intestinal obstruction.
Non-absorbable antibiotics:

- rifaximin hepatic encephalopathy.

Acidify the gut and promote
Caution: renal impairment Creatinine clearance $<30 \mathrm{~mL} / \mathrm{min}$ ).
Must be started by (or in consultation with) a gastroenterologist or hepatologist.

Use concomitantly with lactulose if tolerated. obstruction.

Caution: Child-Pugh C cirrhosis (increased systemic activity). 


\section{Alcoholic hepatitis}

Alcoholic hepatitis can be a life-threatening condition associated with heavy alcohol use. It usually presents with jaundice and a characteristic pattern of liver biochemistry (Table 1). 9,17 Symptoms can include fever, right upper-quadrant or epigastric pain and tenderness, and occasionally ascites or hepatic encephalopathy. Infection and sepsis are relatively common and severe complications of alcoholic hepatitis leading to poor outcomes. ${ }^{22}$ Mortality associated with alcoholic hepatitis is high and immediate referral to hospital for assessment, support and treatment is essential. , $16^{16}$

Treatment of alcoholic hepatitis focuses on nutritional support and complete abstinence from alcohol. In severe cases corticosteroids may be considered, although evidence for their effectiveness remains inconclusive. ${ }^{33}$ Patients may be discharged with oral prednisolone to complete a 28-day course, followed by an optional three-week taper. ${ }^{22}$ Following discharge from hospital, GP review and timely cessation of temporary concomitant therapies such as proton pump inhibitors may be helpful to prevent inappropriate long-term use. Re-introduction of temporarily withheld medications (e.g. nephrotoxic drugs including diuretics, ACE inhibitors and sartans) can be considered when renal function has stabilised.

\section{Nutritional deficiency}

Malnourishment is prevalent in alcohol-associated liver disease due to poor oral intake, hypermetabolism, altered nutritional requirements and malabsorption of fats. ${ }^{34}$ Correction of pancreatic insufficiency (e.g. pancreatic enzyme replacement) and nutritional support may be required to maintain muscle mass and prevent catabolism (energy intake $25-40 \mathrm{kcal} / \mathrm{kg} /$ day and protein intake 1-1.5 g/ $\mathrm{kg} /$ day). ${ }^{34,35}$ Multivitamins and supplements to correct specific deficiencies are also commonly used in clinical practice.

In all stages of alcohol-associated liver disease, vitamin $\mathrm{B}_{1}$ (thiamine) supplementation is strongly recommended to prevent neurological complications like Wernicke-Korsakoff's syndrome. ${ }^{31}$ If WernickeKorsakoff's syndrome is suspected (e.g. acute confusion, delirium), immediate referral to hospital is required. Vitamin $B_{12}$ supplementation is also recommended in deficiency to prevent neuropathies and megaloblastic anaemia. ${ }^{31}$

Supplementation of fat-soluble vitamins (A, D, E and $\mathrm{K}$ ) is not routinely recommended, except for vitamin $D$ deficient patients with cirrhosis or bone disease. ${ }^{25,31}$ The benefits of supplementing other micronutrients including ascorbic acid, magnesium and selenium are debated and they are not routinely recommended in clinical practice. Antioxidants including beta-carotene, vitamin A, vitamin C, vitamin $\mathrm{E}$ and selenium have been trialled to reduce oxidative stress and liver damage. However, a Cochrane review found no evidence to support these supplements in patients with liver disease. ${ }^{36}$

\section{Alcoholic cirrhosis}

Progression of liver disease in the setting of ongoing alcohol consumption and other risk factors can lead to cirrhosis (Fig.). These patients may experience asymptomatic disease ('compensated') or present with complications of portal hypertension and liver insufficiency ('decompensated'). ${ }^{26,37}$ All patients with suspected cirrhosis should be referred for specialist evaluation.

Cirrhosis can potentially reduce clearance and increase exposure to certain drugs or metabolites ${ }^{38}$ due to:

- altered drug absorption (rate and extent of absorption)

- abnormal distribution and impaired synthetic function (fluid accumulation and hypoalbuminaemia)

- reduced metabolism of endogenous and exogenous substances

- altered elimination processes via hepatic and renal pathways.

Consequently, people with cirrhosis are at greater risk of experiencing adverse drug reactions compared to those with non-cirrhotic liver disease. ${ }^{39}$ This is especially the case for patients with complications like ascites, hepatic encephalopathy, jaundice and variceal bleeding who are at higher risk of pharmacodynamic interactions.

Practical prescribing recommendations for individual medicines (based on pharmacokinetic changes) are available to guide drug selection and dose adjustments for people with cirrhosis..$^{40,41}$ Progression to Child-Pugh B/C cirrhosis increases the likelihood of pharmacokinetic changes and pharmacodynamic interactions, ${ }^{41}$ especially among potentially inappropriate medicines (Table 3). ${ }^{15,18,20,21,29,40-44}$ Even medicines that are regularly used to manage the complications of cirrhosis such as diuretics, lactulose and nonselective beta blockers require regular titration and monitoring to prevent medication-related harm due to pharmacodynamic changes (e.g. dehydration, electrolyte derangement, hypotension). 
Table 3 Potentially inappropriate medicines in alcohol-associated liver disease 15,18,20,21,29,40-44

\begin{tabular}{|c|c|c|}
\hline Drug & Stage to avoid use & Medication safety considerations \\
\hline \multirow{5}{*}{$\begin{array}{l}\text { ACE inhibitors and sartans: } \\
\text { - e.g. ramipril, perindopril, } \\
\text { irbesartan, telmisartan }\end{array}$} & Alcoholic hepatitis & \multirow{4}{*}{$\begin{array}{l}\text { Increased risk of interactions with increasing } \\
\text { severity of liver disease due to progressive } \\
\text { alteration in renal haemodynamics. } \\
\text { Commence at a low dose and titrate slowly. }\end{array}$} \\
\hline & Cirrhosis & \\
\hline & \multirow{3}{*}{$\begin{array}{l}\text { Especially patients with ascites } \\
\text { or renal impairment }\end{array}$} & \\
\hline & & \\
\hline & & $\begin{array}{l}\text { The risk of harm in Child-Pugh C cirrhosis may } \\
\text { outweigh benefits. }\end{array}$ \\
\hline
\end{tabular}

\section{Antibiotics:}

Alcohol use disorder

- metronidazole, nitrofurantoin, sulfamethoxazole
Antiplatelets and anticoagulants:

- e.g. ticagrelor, dabigatran, rivaroxaban

Cirrhosis (varies by drug class)

Interaction with alcohol may lead to disulfiramlike reactions (nausea, vomiting, flushing, headache, palpitations).

Patients should avoid consuming alcohol during treatment and for 24 hours after finishing the course.

Nitrofurantoin may cause drug-induced liver injury.

Standard markers of haemostasis (INR, prothrombin time, platelet count) do not accurately reflect coagulative status.

Low-molecular-weight heparins and vitamin $\mathrm{K}$ antagonists are preferred to manage venous thromboembolism.

Limited experience with direct-acting oral anticoagulants. Avoid use in advanced cirrhosis.

Clopidogrel and prasugrel appear safe in Child-Pugh A and B cirrhosis. Safety of ticagrelor in advanced cirrhosis is unknown. Aspirin appears safe.

Benzodiazepines:

- e.g. diazepam, oxazepam, temazepam
Alcohol use disorder

Cirrhosis

Especially patients with history of hepatic encephalopathy
Alcohol consumption enhances the sedative effect of benzodiazepines including drowsiness, sedation and impaired motor skills.

Even short-term use can precipitate hepatic encephalopathy.

If a benzodiazepine is indicated, oxazepam or temazepam are preferred due to the comparatively simple hepatic metabolism.

If a calcium channel blocker is indicated, amlodipine, nifedipine and diltiazem appear safe if commenced at a low dose and titrated slowly.

Felodipine, lercanidipine and verapamil should be avoided in Child-Pugh $\mathrm{C}$ cirrhosis.

Alcohol consumption increases the risk of peptic ulcer disease and gastrointestinal bleeding.

Increased risk of renal impairment, acute kidney injury and hepatorenal syndrome in acute and chronic hepatic impairment.

All non-steroidal anti-inflammatory drugs should be avoided. Paracetamol is a safe alternative (maximum 2-3 g daily in malnourished patients and those with cirrhosis). 
Table 3 Potentially inappropriate medicines in alcohol-associated liver disease 15,18,20,21,29,40-44 (continued)

\begin{tabular}{|c|c|c|}
\hline Drug & Stage to avoid use & Medication safety considerations \\
\hline \multirow{7}{*}{$\begin{array}{l}\text { Opioids: } \\
\text { - e.g. oxycodone, tramadol, } \\
\text { morphine, tapentadol }\end{array}$} & \multirow{7}{*}{$\begin{array}{l}\text { Alcohol use disorder } \\
\text { Cirrhosis } \\
\text { Especially patients with history } \\
\text { of hepatic encephalopathy }\end{array}$} & \multirow{4}{*}{$\begin{array}{l}\text { Alcohol consumption enhances the sedative } \\
\text { effect of opioids including drowsiness, sedation } \\
\text { and impaired motor skills. } \\
\text { May precipitate hepatic encephalopathy, especially } \\
\text { in patients not taking appropriate laxatives. }\end{array}$} \\
\hline & & \\
\hline & & \\
\hline & & \\
\hline & & $\begin{array}{l}\text { All slow-release formulations (especially } \\
\text { patches) should be avoided due to reversal } \\
\text { difficulties if hepatic encephalopathy occurs. }\end{array}$ \\
\hline & & $\begin{array}{l}\text { If an opioid is indicated, immediate-release } \\
\text { tramadol or oxycodone appear safe if } \\
\text { commenced at a low dose and titrated slowly. } \\
\text { Use paracetamol as an opioid-sparing drug. }\end{array}$ \\
\hline & & Avoid tapentadol in Child-Pugh C cirrhosis. \\
\hline \multirow{4}{*}{$\begin{array}{l}\text { Proton pump inhibitors: } \\
\text { - e.g. pantoprazole, } \\
\text { rabeprazole, omeprazole }\end{array}$} & \multirow{4}{*}{$\begin{array}{l}\text { Nutritional deficiency } \\
\text { Cirrhosis } \\
\text { Especially patients with } \\
\text { ascites, history of hepatic } \\
\text { encephalopathy, or recurrent } \\
\text { infections }\end{array}$} & \multirow{3}{*}{$\begin{array}{l}\text { Inhibition of gastric acid secretion alters } \\
\text { bioavailability and absorption of vitamins and } \\
\text { minerals. } \\
\text { If a proton pump inhibitor is indicated, (es) } \\
\text { omeprazole and rabeprazole appear safe at } \\
\text { low doses. Esomeprazole may be safest in } \\
\text { Child-Pugh C cirrhosis. }\end{array}$} \\
\hline & & \\
\hline & & \\
\hline & & $\begin{array}{l}\text { People with cirrhosis often have impaired } \\
\text { immunity. Inhibition of gastric acid secretion } \\
\text { further increases infection risk, especially } \\
\text { spontaneous bacterial peritonitis and } \\
\text { Clostridium difficile infection. }\end{array}$ \\
\hline \multirow{4}{*}{$\begin{array}{l}\text { Oral hypoglycaemic drugs: } \\
\text { - e.g. metformin, sulfonylureas, } \\
\text { dipeptidyl peptidase-4 } \\
\text { inhibitors, sodium-glucose } \\
\text { co-transporter } 2 \text { inhibitors, } \\
\text { pioglitazone }\end{array}$} & \multirow[t]{4}{*}{ Cirrhosis (varies by drug class) } & $\begin{array}{l}\text { Metformin has a favourable safety profile and } \\
\text { numerous benefits in chronic liver disease. } \\
\text { There is conflicting evidence about the risk of } \\
\text { lactic acidosis in advanced cirrhosis. }\end{array}$ \\
\hline & & $\begin{array}{l}\text { Avoid sulfonylureas in cirrhosis due to the risk } \\
\text { of hypoglycaemia. }\end{array}$ \\
\hline & & Avoid pioglitazone in advanced cirrhosis. \\
\hline & & $\begin{array}{l}\text { Limited experience with dipeptidyl peptidase- } 4 \\
\text { inhibitors and sodium-glucose co-transporter } 2 \\
\text { inhibitors in cirrhosis. Dose reduction is often } \\
\text { required. Avoid use in advanced cirrhosis. }\end{array}$ \\
\hline
\end{tabular}

\section{Comorbidities and polypharmacy}

While the comorbidity burden is often lower in alcohol-associated liver disease compared to other types of chronic liver disease (e.g. non-alcoholic fatty liver disease), the prevalence of hypertension (32-41\%), ischaemic heart disease (5-20\%), heart failure (5-12\%) and type 2 diabetes (26-29\%) is notable. ${ }^{45,46}$ Concomitant drugs prescribed for these conditions may require additional monitoring, especially in people with cirrhosis. In those with decompensated cirrhosis who are ineligible for liver transplant, deprescribing medicines for which benefit is with long-term use (e.g. statins) could be considered. This will reduce the medication burden for these patients who will likely follow a palliative course, with a median survival of approximately two years. ${ }^{37}$

\section{Conclusion}

Doctors, nurses, and pharmacists in the primary care setting have an important role in the management of patients with alcohol-associated liver disease. In addition to supporting abstinence, optimising medicine use is imperative to improve outcomes and minimise harm. $<$

Conflicts of interest: Kelly Hayward was supported by a Health Innovation, Investment and Research Office (HIIRO) Clinical Research Fellowship. 
1. Australian Government Department of Health. How much alcohol is safe to drink? Updated 8 December 2020. https://www.health.gov.au/health-topics/alcohol/aboutalcohol/how-much-alcohol-is-safe-to-drink [cited 2021 May 1]

2. Australian Bureau of Statistics. National health survey: first results, 2017-18. 12 December 2020. https://www.abs.gov.au/ statistics/health/health-conditions-and-risks/nationalhealth-survey-first-results/latest-release [cited 2021 May 1]

3. National Institute on Alcohol Abuse and Alcoholism. Alcohol use disorder. https://www.niaaa.nih.gov/alcohols-effectshealth/alcohol-use-disorder [cited 2021 May 1]

4. Gao B, Bataller R. Alcoholic liver disease: pathogenesis and new therapeutic targets. Gastroenterology 2011;141:1572-85. https://doi.org/10.1053/j.gastro.2011.09.002

5. Huang Y, Joseph J, de Boer WB, Cheng W, Adams LA, MacQuillan G, et al. Long-term liver-related outcomes of patients with chronic liver diseases in Australia. Clin Gastroenterol Hepatol 2020;18:496-504.e3. https://doi.org/10.1016/j.cgh.2019.07.013

6. Crabb DW, Im GY, Szabo G, Mellinger JL, Lucey MR. Diagnosis and treatment of alcohol-associated liver diseases: 2019 practice guidance from the American Association for the Study of Liver Diseases. Hepatology 2020;71:306-33. https://doi.org/10.1002/hep.30866

7. Lombardi R, Buzzetti E, Roccarina D, Tsochatzis EA. Noninvasive assessment of liver fibrosis in patients with alcoholic liver disease. World J Gastroenterol 2015;21:11044-52. https://doi.org/10.3748/wjg.v21.i39.11044

8. Moreno C, Mueller S, Szabo G. Non-invasive diagnosis and biomarkers in alcohol-related liver disease. J Hepato 2019;70:273-83. https://doi.org/10.1016/j.jhep.2018.11.025

9. Crabb DW, Bataller R, Chalasani NP, Kamath PS, Lucey M Mathurin P, et al.; NIAAA Alcoholic Hepatitis Consortia. Standard definitions and common data elements for clinical trials in patients with alcoholic hepatitis: recommendation from the NIAAA Alcoholic Hepatitis Consortia. Gastroenterology 2016;150:785-90. https://doi.org/10.1053/j.gastro.2016.02.042

10. Diehl AM. Liver disease in alcohol abusers: clinical perspective. Alcohol 2002;27:7-11. https://doi.org/10.1016/ S0741-8329(02)00204-5

11. Kazemi-Shirazi L, Veloso MP, Frommlet F, Steindl-Munda P, Wrba F, Zehetmayer S, et al. Differentiation of nonalcoholic from alcoholic steatohepatitis: are routine laboratory markers useful? Wien Klin Wochenschr 2008;120:25-30. https://doi.org/10.1007/s00508-007-0921-1

12. Lowinger JS, Maxwell DJ. Heparins for venous thromboembolism prophylaxis - safety issues. Aust Prescr 2009;32:108-12. https://doi.org/10.18773/austprescr.2009.051

13. Morita Y, Ueno T, Sasaki N, Kuhara K, Yoshioka S, Tateishi Y, et al. Comparison of liver histology between patients with non-alcoholic steatohepatitis and patients with alcoholic steatohepatitis in Japan. Alcohol Clin Exp Res 2005;29(Suppl):277S-81S. https://doi.org/10.1097/01. alc.0000191777.36629.33

14. Nyblom H, Berggren U, Balldin J, Olsson R. High AST/ALT ratio may indicate advanced alcoholic liver disease rather than heavy drinking. Alcohol Alcohol 2004;39:336-9. https://doi.org/10.1093/alcalc/agh074

15. Patel SS, Guzman LA, Lin FP, Pence T, Reichman T, John B, et al. Utilization of aspirin and statin in management of coronary artery disease in patients with cirrhosis undergoing liver transplant evaluation. Liver Transpl 2018;24:872-80. https://doi.org/10.1002/lt.25067

16. Saberi B, Dadabhai AS, Jang YY, Gurakar A, Mezey E. Current management of alcoholic hepatitis and future therapies. J Clin Transl Hepatol 2016:4:113-22. https://doi.org/10.14218/jcth.2016.00006

17. Sorbi D, Boynton J, Lindor KD. The ratio of aspartate aminotransferase to alanine aminotransferase: potential value in differentiating nonalcoholic steatohepatitis from alcoholic liver disease. Am J Gastroenterol 1999;94:1018-22. https://doi.org/10.1111/j.1572-0241.1999.01006.x

18. Weathermon R, Crabb DW. Alcohol and medication interactions. Alcohol Res Health 1999;23:40-54.

19. Center for Substance Abuse Treatment. Incorporating alcohol pharmacotherapies into medical practice. Treatment Improvement Protocol (TIP) Series, No. 49. Rockville (MD): Substance Abuse and Mental Health Services Administration (US); 2009
20. Hayward KL, Powell EE, Irvine KM, Martin JH. Can paracetamol (acetaminophen) be administered to patients with liver impairment? Br J Clin Pharmacol 2016;81:210-22. https://doi.org/10.1111/bcp.12802

21. Imani F, Motavaf M, Safari S, Alavian SM. The therapeutic use of analgesics in patients with liver cirrhosis: a literature review and evidence-based recommendations. Hepat Mon 2014:14:e23539. https://doi.org/10.5812/hepatmon.23539

22. European Association for the Study of the Liver. EASL Clinical Practice Guidelines: management of alcohol-related liver disease. J Hepatol 2018;69:154-81. https://doi.org/ 10.1016/j.jhep.2018.03.018

23. Masson S, Emmerson I, Henderson E, Fletcher EH, Burt AD, Day CP, et al. Clinical but not histological factors predict long-term prognosis in patients with histologically advanced non-decompensated alcoholic liver disease. Liver Int 2014;34:235-42. https://doi.org/10.1111/liv.12242

24. Crowley P. Long-term drug treatment of patients with alcohol dependence. Aust Prescr 2015;38:41-3. https://doi.org/10.18773/austprescr.2015.015

25. Bjelakovic G, Nikolova D, Bjelakovic M, Gluud C. Vitamin D supplementation for chronic liver diseases in adults. Cochrane Database Syst Rev 2017;11:CD011564. https://doi.org/10.1002/14651858.CD011564.pub2

26. European Association for the Study of the Liver. EASL Clinical Practice Guidelines for the management of patients with decompensated cirrhosis. J Hepatol 2018;69:406-60. https://doi.org/10.1016/j.jhep.2018.03.024

27. Fuster D, Samet JH. Alcohol use in patients with chronic liver disease. N Engl J Med 2018;379:1251-61. https://doi.org/ 10.1056/NEJMra1715733

28. García ML, Blasco-Algora S, Fernández-Rodríguez CM Alcohol liver disease: a review of current therapeutic approaches to achieve long-term abstinence. World J Gastroenterol 2015;21:8516-26. https://doi.org/ 10.3748/wjg.v21.i28.8516

29. Grønbæk L, Watson H, Vilstrup H, Jepsen P. Benzodiazepines and risk for hepatic encephalopathy in patients with cirrhosis and ascites. United European Gastroenterol J 2018:6:407-12. https://doi.org/10.1177/2050640617727179

30. McClain C, Vatsalya V, Cave M. Role of zinc in the development/progression of alcoholic liver disease. Curr Treat Options Gastroenterol 2017;15:285-95 https://doi.org/10.1007/s11938-017-0132-4

31. Rossi RE, Conte D, Massironi S. Diagnosis and treatment of nutritional deficiencies in alcoholic liver disease: overview of available evidence and open issues. Dig Liver Dis 2015;47:819-25. https://doi.org/10.1016/j.dld.2015.05.021

32. Sullivan JT, Sykora K, Schneiderman J, Naranjo CA, Sellers EM. Assessment of alcohol withdrawal: the revised clinical institute withdrawal assessment for alcohol scale (CIWA-Ar). Br J Addict 1989;84:1353-7. https://doi.org/ 10.1111/j.1360-0443.1989.tb00737.x

33. Thursz MR, Richardson P, Allison M, Austin A, Bowers M, Day CP, et al.; STOPAH Trial. Prednisolone or pentoxifylline for alcoholic hepatitis. N Engl J Med 2015;372:1619-28. https://doi.org/10.1056/NEJMoa1412278

34. Eghtesad S, Poustchi H, Malekzadeh R. Malnutrition in liver cirrhosis: the influence of protein and sodium. Middle East J Dig Dis 2013;5:65-75.

35. Plauth M, Bernal W, Dasarathy S, Merli M, Plank LD, Schütz T, et al. ESPEN guideline on clinical nutrition in liver disease. Clin Nutr 2019;38:485-521. https://doi.org/10.1016/ j.clnu.2018.12.022

36. Bjelakovic G, Gluud LL, Nikolova D, Bjelakovic M, Nagorni A Gluud C. Meta-analysis: antioxidant supplements for liver diseases - the Cochrane Hepato-Biliary Group. Aliment Pharmacol Ther 2010;32:356-67. https://doi.org/ 10.1111/j.1365-2036.2010.04371.x

37. D’Amico G, Garcia-Tsao G, Pagliaro L. Natural history and prognostic indicators of survival in cirrhosis: a systematic review of 118 studies. J Hepatol 2006;44:217-31. https://doi.org/10.1016/j.jhep.2005.10.013

38. Weersink RA, Burger DM, Hayward KL, Taxis K, Drenth JP, Borgsteede SD. Safe use of medication in patients with cirrhosis: pharmacokinetic and pharmacodynamic considerations. Expert Opin Drug Metab Toxicol 2020;16:45-57. https://doi.org/10.1080/17425255.2020.1702022 
39. Naranjo CA, Busto $U$, Mardones R. Adverse drug reactions in liver cirrhosis. Eur J Clin Pharmacol 1978:13:429-34. https://doi.org/10.1007/BF00566321

40. Lewis JH, Stine JG. Review article: prescribing medications in patients with cirrhosis - a practical guide. Aliment Pharmacol Ther 2013;37:1132-56. https://doi.org/ 10.1111/apt.12324

41. Weersink RA, Bouma M, Burger DM, Drenth JP, Harkes-Idzinga SF, Hunfeld NG, et al. Evidence-based recommendations to improve the safe use of drugs in patients with liver cirrhosis. Drug Saf 2018;41:603-13. https://doi.org/10.1007/s40264-017-0635-x

42. Heidelbaugh JJ. Proton pump inhibitors and risk of vitamin and mineral deficiency: evidence and clinical implications. Ther Adv Drug Saf 2013;4:125-33. https://doi.org/10.1177/ 2042098613482484
43. Sumida Y, Yoneda M, Tokushige K, Kawanaka M, Fujii $H$, Yoneda M, et al. Antidiabetic treatments for diabetes with liver cirrhosis. Interventions Obes Diabetes 2020;3:273-9. https://doi.org/10.31031/IOD.2020.03.000566

44. Turco L, de Raucourt E, Valla DC, Villa E. Anticoagulation in the cirrhotic patient. JHEP Rep 2019;1:227-39. https://doi.org/ 10.1016/j.jhepr.2019.02.006

45. Vaz J, Eriksson B, Strömberg U, Buchebner D, Midlöv P. Incidence, aetiology and related comorbidities of cirrhosis: a Swedish population-based cohort study. BMC Gastroenterol 2020;20:84. https://doi.org/10.1186/s12876-020-01239-6

46. Yang TW, Wang CC, Tsai MC, Wang YT, Tseng MH, Lin CC. Comorbidities and outcome of alcoholic and non-alcoholic liver cirrhosis in Taiwan: a population-based study. Int J Environ Res Public Health 2020;17:2825. https://doi.org/ 10.3390/ijerph17082825

\section{FURTHER READING}

Crabb DW, Im GY, Szabo G, Mellinger JL, Lucey MR. Diagnosis and treatment of alcohol-associated liver diseases: 2019 practice guidance from the American Association for the Study of Liver Diseases. Hepatol 2020;71:306-33. https://doi.org/10.1002/ hep.30866
Sloss A, Kubler P. Prescribing in liver disease. Aust Prescr 2009;32:32-5. https://doi.org/10.18773/austprescr.2009.018 